\title{
COMMENT
}

\section{Recent changes in the Rio Cruces: Comment on Mulsow \& Grandjean (2006)}

\author{
Lee Harding ${ }^{1, *}$, Julius Pretorius ${ }^{2}$, Michael McGurk ${ }^{2}$
}

\begin{abstract}
${ }^{1}$ SciWrite Environmental Sciences Ltd., 2339 Sumpter Drive, Coquitlam, British Columbia V3J 6Y3, Canada ${ }^{2}$ Rescan Environmental Services Ltd., Sixth Floor, 1111 West Hastings Street, Vancouver, British Columbia V6E 2J3, Canada
\end{abstract}

\section{INTRODUCTION}

Mulsow \& Grandjean (2006) concluded that the disappearance of Brazilian waterweed Egeria densa from the Carlos Anwandter Nature Sanctuary (henceforth, 'the Sanctuary') was due to diminished bicarbonate $\left(\mathrm{HCO}_{3}{ }^{-}\right)$levels in the estuary. Based on results obtained from microcosm experiments and chemical speciation calculations, they ascribed a decrease in $\mathrm{HCO}_{3}{ }^{-}$concentration to elevated sulfate levels emanating from effluent from the Celulosa Arauco y Constitución SA (CELCO) pulp mill. We have identified a number of problems with the work reported by Mulsow \& Grandjean (2006) that invalidate their conclusions. These erroneous conclusions can only detract from the quest of discovering the event, or combination of events, that led to the virtual disappearance of Brazilian waterweed and the decline in numbers of waterbirds in the Sanctuary.

\section{CHEMICAL CONSIDERATIONS}

The assertion of Mulsow \& Grandjean (2006) that their study ' ...demonstrates that $\mathrm{SO}_{4}\left[\mathrm{sic}, \mathrm{SO}_{4}{ }^{2-}\right]$ salts ... forced the $\mathrm{CO}_{2} / \mathrm{HCO}_{3} / \mathrm{CO}_{3}\left[\mathrm{sic}, \mathrm{CO}_{2} / \mathrm{HCO}_{3}{ }^{-} / \mathrm{CO}_{3}{ }^{2-}\right]$ equilibrium towards an ecologically and statistically significant decrease in $\left(\mathrm{HCO}_{3}\right)^{-}\left[\mathrm{sic}, \mathrm{HCO}_{3}^{-}\right] \ldots$ is not supported by the behavior of the carbonate system $\left(\mathrm{CO}_{2}-\mathrm{H}_{2} \mathrm{CO}_{3}-\mathrm{HCO}_{3}^{-}-\mathrm{CO}_{3}^{2-}\right)$ in natural waters. Moreover, contrary to the statement of Mulsow \& Grandjean (2006), CELCO has never discharged $\mathrm{H}_{2} \mathrm{SO}_{4}$ into the Río Cruces (Andres Camaño, Corporate Environmental Director, CELCO, Santiago, Chile, pers. comm., August 9, 2006). Its effluent pH averaged 6.47 in daily monitoring since start-up $(n=739$, range
5.76 to 7.58 ; CELCO effluent records are regularly posted on the website of CONAMA [Comision Nacional del Medio Ambiente], the regulatory authority, at www.conama.cl/portal/1255/article-33574 .html). The lower $\mathrm{pH}$ at some downstream locations reflects the presence of natural humic and tannic acids in boggy marshes separated from the main channel. For example, Steubing et al. (1980) measured a mean pH 5.8 in Río Cruces marshes, compared to 6.4 in the main river channel.

Using the well known chemistry of the carbonate system (e.g. Stumm \& Morgan 1996, Langmuir 1997), it is easy to show that, for an open system, $\mathrm{pH}$ and $\mathrm{CO}_{2}$ partial pressure determine the concentration of total carbonate and its distribution among the species $\mathrm{H}_{2} \mathrm{CO}_{3}, \mathrm{HCO}_{3}{ }^{-}$and $\mathrm{CO}_{3}{ }^{2-}$ in aqueous solution. In a system open to the atmosphere, the partial pressure of atmospheric $\mathrm{CO}_{2}$ is constant at $10^{-3.5}$ atm, leaving $\mathrm{pH}$ as the master variable determining carbonate chemistry. Carbonate chemistry shows that, at $\mathrm{pH}$ lower than about $6, \mathrm{H}_{2} \mathrm{CO}_{3}$ (aq.) is the dominant species. In this $\mathrm{pH}$ region, loss of total carbonate due to $\mathrm{CO}_{2}$ formation may occur. $\mathrm{HCO}_{3}{ }^{-}$dominates in the $\mathrm{pH}$ range 6 to 10 . At $\mathrm{pH}>10, \mathrm{CO}_{3}{ }^{2-}$ dominates.

In their microcosm experiments, Mulsow \& Grandjean (2006) added sulfate as $\mathrm{K}_{2} \mathrm{SO}_{4} . \mathrm{K}_{2} \mathrm{SO}_{4}$ is a neutral salt that will not decrease the $\mathrm{pH}$ of an aqueous solution. $\mathrm{K}^{+}$does not hydrolyze readily and will therefore not decrease $\mathrm{pH}$. $\mathrm{SO}_{4}{ }^{2-}$ will lead to a modest increase in solution $\mathrm{pH}$ due to its capacity to scavenge protons. The addition of pure $0.1 \mathrm{~mol} \mathrm{dm}{ }^{-3} \mathrm{~K}_{2} \mathrm{SO}_{4}$ to degassed, distilled water increases $\mathrm{pH}$ by about 0.3 units. This neutrality of $\mathrm{K}_{2} \mathrm{SO}_{4}$ towards $\mathrm{pH}$, together with the $\mathrm{pH}$ dependence of the carbonate system, argues against $\mathrm{SO}_{4}{ }^{2-}$ being capable of influencing $\mathrm{HCO}_{3}{ }^{-}$concentration in aqueous solution. 
Mulsow \& Grandjean (2006) appear to regard the species $\mathrm{HCO}_{3}^{-}$and $\mathrm{CaHCO}_{3}{ }^{+}$as being equivalent. That is chemically incorrect since these are 2 distinct chemical species with quite different chemical behaviors. Moreover, to equate a decrease in $\mathrm{CaHCO}_{3}{ }^{+}$ (which will occur due to $\mathrm{SO}_{4}{ }^{2-}$ and $\mathrm{HCO}_{3}{ }^{-}$competing for $\mathrm{Ca}^{2+}$ ) to a decrease in $\mathrm{HCO}_{3}{ }^{-}$reveals a lack of understanding of solution chemistry in general. In fact, $\mathrm{SO}_{4}{ }^{2-}$ competition will result in an increase in $\mathrm{HCO}_{3}$ concentration, due to the less $\mathrm{Ca}^{2+}$ available to complex with $\mathrm{HCO}_{3}{ }^{-}$.

The microcosm experiments of Mulsow \& Grandjean (2006) did exhibit a decrease in $\mathrm{pH}$ with increased $\mathrm{K}_{2} \mathrm{SO}_{4}$ concentration. This was most likely due to impurities in the $\mathrm{K}_{2} \mathrm{SO}_{4}$ salt, or other experimental quality control issues. Mulsow \& Grandjean (2006) do not mention reagent purity. Analytical grade $\mathrm{K}_{2} \mathrm{SO}_{4}$ commonly contains up to $1 \%$ impurities (see ChemDAT: The Merck Chemical Databases [http:// chemdat.merck.de]).

Mulsow \& Grandjean (2006) contend that calcium is removed from solution via the precipitation of gypsum $\left(\mathrm{CaSO}_{4} \cdot 2 \mathrm{H}_{2} \mathrm{O}\right)$, portlandite $\left(\mathrm{Ca}(\mathrm{OH})_{2}\right)$ and brucite $\left(\mathrm{Mg}(\mathrm{OH})_{2}\right)$. Gypsum formation requires concentrations of about $1600 \mathrm{mg} \mathrm{dm}^{-3} \mathrm{SO}_{4}{ }^{2-}$ and $667 \mathrm{mg} \mathrm{dm}^{-3} \mathrm{Ca}^{2+}$. According to Mulsow \& Grandjean (2006), the maximum sulfate concentration in the sanctuary is about $4.5 \mathrm{mg} \mathrm{dm}^{-3}$. This is too low for gypsum to precipitate. Portlandite and brucite require $\mathrm{pH}>10$ to form (Langmuir 1997). In monthly monitoring since start-up of the CELCO mill, mean pH values in Río Cruces approximately $1 \mathrm{~km}$ above and $2 \mathrm{~km}$ below the CELCO discharge were 7.08 and 7.03, respectively (Arauco 2006). These values were not significantly different (paired $t$ test, $\mathrm{p}<0.0001, \mathrm{n}=24$ ). At this $\mathrm{pH}$, neither portlandite nor brucite will form. Since the speciation calculations of Mulsow \& Grandjean (2006) showed these solids to form, their model must have been wrong.

\section{MICROCOSM EXPERIMENTS}

In their microcosm experiments, Mulsow \& Grandjean (2006) confused exposure concentration with duration. Their bioassays doses were equivalent to the sulfate loading of 15,30 , and $60 \mathrm{~d}$ of CELCO effluent, resulting in concentrations of 2500, 4500 (or 4900; Mulsow \& Grandjean 2006 gave both values at different places in the manuscript), and $9800 \mathrm{mg} \mathrm{dm}^{-3}$. The highest measured concentration in the study area reported by Mulsow \& Grandjean (2006) was $4.52 \mathrm{mg} \mathrm{dm}^{-3}$. Therefore, the experimental concentrations were 553 to 2168 times greater than the highest concentration of sulfate measured in the Río Cruces, a significant departure from conditions within the Sanctuary.
In explaining the poor health of Brazilian waterweed in their microcosms, Mulsow \& Grandjean (2006) stated that it is a $\mathrm{C}_{4}$ plant. In fact, Brazilian waterweed is a facultative $\mathrm{C}_{4}$ plant, which means that it can utilize either the $\mathrm{C}_{3}$ or the $\mathrm{C}_{4}$ metabolic pathways depending on environmental conditions (Holaday et al. 1983, Bowes et al. 2002). While Brazilian waterweed can utilize $\mathrm{HCO}_{3}{ }^{-}$, it is more efficient at utilizing $\mathrm{CO}_{2}$ (Bowes et al. 2002). Consequently, Brazilian waterweed will only use $\mathrm{HCO}_{3}{ }^{-}$when $\mathrm{CO}_{2}$ concentrations become limiting. Under low $\mathrm{CO}_{2}$ conditions, Brazilian waterweed acidifies its surroundings to ca. pH 4.0 (Bowes et al. 2002). Within this acidic zone, $\mathrm{HCO}_{3}{ }^{-}$is converted to $\mathrm{CO}_{2}$ via $\mathrm{H}_{2} \mathrm{CO}_{3}$ (aq.). The $\mathrm{CO}_{2}$ is then utilized by the plant (Prins et al. 1982). However, there is no evidence that $\mathrm{CO}_{2}$ was limiting anywhere in the Sanctuary.

A more probable explanation for the poor growth of Brazilian waterweed in the experiments reported by Mulsow \& Grandjean (2006) was the choice of potassium sulfate $\left(\mathrm{K}_{2} \mathrm{SO}_{4}\right)$ to simulate sulfate exposure. The potassium ion, $\mathrm{K}^{+}$, is more toxic to freshwater organisms than, for example, sodium and calcium (Mount et al. 1997). Mulsow \& Grandjean (2006) appear to be unaware of the possibility that $\mathrm{K}^{+}$may be responsible for the effects they observe, especially since potassium was present at twice the sulfate concentration in their microcosm test solutions. Healthy Brazilian waterweed has been observed in systems with significantly lower $\mathrm{HCO}_{3}{ }^{-}$concentrations and significantly higher sulfate concentrations than those reported in their microcosm experiments and in the Río Cruces (Timperley \& VigorBrown 1986, Bartodziej \& Leslie 1998, Parsons 1999, University of Florida 1999, Mazzeo et al. 2003, Pezzato \& Camargo 2004, Wilcock \& Croker 2004).

\section{CONCLUSIONS}

$\mathrm{pH}$ is the dominant determinant of the abundance of $\mathrm{HCO}_{3}{ }^{-}$. Because $\mathrm{SO}_{4}{ }^{2-}$ does not affect the $\mathrm{pH}$ of an aqueous solution, it is not possible for it to adversely affect $\mathrm{HCO}_{3}{ }^{-}$abundance. Furthermore, since $\mathrm{pH}$ levels in Río Cruces above and below the CELCO discharge are virtually identical, it cannot have affected $\mathrm{HCO}_{3}{ }^{-}$ concentrations. The chemical speciation model of Mulsow \& Grandjean (2006), or their modeling procedure, appears to be flawed due to both the decrease in $\mathrm{HCO}_{3}{ }^{-}$and the precipitation of solids that it predicts. Effects of increased sulfate or decreased bicarbonate on Brazilian waterweed must also be rejected on biological grounds. This does not preclude the possibility that effluent from the CELCO pulp mill may have caused adverse effects in the sanctuary. It does, however, suggest caution in accepting facile statements as to cause and effect. A multi-disciplinary study is 
required to unravel the events that caused the virtual disappearance of Brazilian waterweed and the decline of waterbirds in the Sanctuary.

Disclosure: This study was funded by Celulosa Arauco y Constitución SA.

\section{LITERATURE CITED}

Arauco (2006) Programa de Monitoreo Ambiental Trimestre I Enero-Febrero-Marzo 2006. Celulosa Arauco y Constitución SA informe al Comisión Nacional del Medio Ambiente GPV 071/2006-C, San José de Mariquina, Chile

Bartodziej W, Leslie AJ (1998) The aquatic ecology and water quality of the St. Marks River, Wakulla County, Florida with emphasis on the role of water-hyacinth: 1989-1995 studies, Florida Department of Environmental Protection, Bureau of Invasive Plant Management. Report No. TSS98-100, Tallahassee, FL

Bowes G, Rao SK, Estavillo GM, Reiskind JB (2002) C4 mechanisms in aquatic angiosperms: comparisons with terrestrial C4 systems. Funct Plant Biol 29:379-392

Holaday AS, Salvucci ME, Bowes G (1983) Variable photosynthesis/photorespiration ratios in Hydrilla and other submersed aquatic macrophyte species. Can J Bot 61: 229-236

Langmuir D (1997) Aqueous environmental geochemistry. Prentice Hall, Upper Saddle River, NJ

Mazzeo N, Rodriguez-Gallego L, Kruk C, Meerhoff M and 6 others (2003) Effects of Egeria densa Planch. beds on a shallow lake without piscivorous fish. Hydrobiologia 506509:591-602

Editorial responsibility: Susan Mooney,

Easton, Massachusetts, USA
Mount DR, Gulley DD, Hockett DR, Garrison TD, Evans JM (1997) Statistical models to predict the toxicity of major ions to Ceriodaphnia dubia, Daphnia magna and Pimephales promelas (Fathead Minnows). Environ Toxicol Chem 16:2009-2019

Mulsow S, Grandjean M (2006) Incompatibility of sulphate compounds and soluble bicarbonate salts in the Río Cruces waters: an answer to the disappearance of Egeria densa and black-necked swans in a RAMSAR sanctuary. ESEP 2006:5-11

Parsons J (1999) Aquatic plants technical assistance program. 1998 activity report, Washington State Department of Ecology Environmental Assessment Program, Olympia, WA

Pezzato MM, Camargo AFM (2004) Photosynthetic rate of the aquatic macrophyte Egeria densa Planch. (Hydrocharitaceae) in two rivers from the Itanhaém River Basin in São Paulo State, Brazil. Brazil Arch Biol Tech 47:153-162

Prins HBA, Snel JFH, Zanstra PE, Halder RJ (1982) The mechanism of bicarbonate assimilation by the polar leaves of Potamogeton and Elodea: $\mathrm{CO}_{2}$ concentrations at the leaf surface. Plant Cell Environ 5:207-214

Steubing L, Ramírez C, Alberdi M (1980) Energy content of water and bog plant associations in the region of Valdivia (Chile). Vegetatio 43:153-161

Stumm W, Morgan JJ (1996) Aquatic chemistry, 3rd edn. John Wiley \& Sons, New York

Timperley MH, Vigor-Brown RJ (1986) Water chemistry of lakes in the Taupo Volcanic Zone, New Zealand. N Z J Mar Freshw Res 20:173-183

University of Florida (1999) Florida LAKEWATCH. Department of Fisheries and Aquatic Sciences. Available at: http://lakewatch.ifas.ufl.edu/

Wilcock RJ, Croker GF (2004) Distribution of carbon between sediment and water in macrophyte dominated lowland streams. Hydrobiologia 520:143-152

Submitted: September 26, 2006; Accepted: December 26, 2006 Proofs received from author(s): January 22, 2007 